\title{
Dietary intakes and some biochemical markers in hemodialysis patients
}

\author{
Emine Yassibas ${ }^{1}$ \\ Gulsah Sahin ${ }^{2}$ \\ Nevin Sanlier ${ }^{3}$
}

\begin{abstract}
Purpose: Intake of energy and some nutrients is frequently inadequate in dialysis patients because of eating and appetite disorders due to uremic syndrome. Inadequate energy and protein intake cause to malnutrition. Anthropometric measurements, biochemical markers and dietary intake records have great importance in determining the nutritional status of hemodialysis (HD) patients. Therefore this study was planned to determination of daily energy, nutrient intake and some biochemical markers of adult hemodialysis patients.

Method and Material: A hundred and thirty six (male $=73$, female $=63$ ) clinically stable HD patients were enrolled in this study. All patients were taken 24-hour dietary recall. The daily energy and nutrient intakes of patients were calculated by food consumption records and anthropometric measurements were taken.

Results: The mean age was found $45.5 \pm 13.51$ years. The ratio of patients with body mass index (BMI) below $18.5 \mathrm{~kg} / \mathrm{m}^{2}$ was $7.4 \%$ and $25 \mathrm{~kg} / \mathrm{m}^{2}$ or upper was $16.9 \%$. Blood hemoglobin, hematocrit, albumin and total protein levels were below the normal levels. The daily dietary energy and protein intakes were found under the recommended level in the study period. A significant positive correlation was found between daily protein intake and serum albumin levels $(r=0.210$, $\mathrm{p}=0.014)$, daily protein intake and serum total protein levels $(\mathrm{r}=0.201, \mathrm{p}=0.019)$, daily energy intake and serum total protein levels $(r=0.178, \mathrm{p}=0.039)$.

Conclusions: HD patients often have low protein and energy intakes and most of them suffer from malnutrition. Therefore nutritional status of patients should be evaluated and periodically nutrition education should be given for improving eating habits and increasing dietary compliance is recommended.
\end{abstract}

Keywords: Hemodialysis; biochemical parameters; diet; energy intake; protein intake

\section{Introduction}

Chronic Renal Failure (CRF) is a growing health problem in the worldwide. CRF which have long, difficult and costly treatment can affect the life quality of patients with complications and itself. CRF is defined as kidney damage and/or decreased kidney function expressed as

\footnotetext{
1 M.Sc., Gazi University, Faculty of Health Sciences, Department of Nutrition and Dietetics, Besevler/ANKARA/TURKEY, eminey2002@hotmail.com

2 M.Sc., Gazi University, Faculty of Health Sciences, Department of Nutrition and Dietetics, Besevler/ANKARA/TURKEY, gulsah.kahya@gmail.com

3 Prof. Dr., Gazi University, Faculty of Health Sciences, Department of Nutrition and Dietetics, Besevler/ANKARA/TURKEY, ntekgul@gazi.edu.tr, nevintekgul@gmail.com
} 
glomerular filtration rate (GFR) for at least 3 months, regardless of the cause (Süleymanlar, 2011, p. 1862).

The prevalence of CRF 1 to 4 increased from 10.0\% in 1988-1994 to 13.1\% in 1999-2004 according to the National Health and Nutrition Examination Study (NHANES) (Coresh et al., 2007, p. 2038). According to the Turkish Society of Nephrology (TSN) 2008 data, the incidence of end stage renal disease (ESRD) in Turkey has increased nearly 4-fold since 2000 (Serdengeçti et al., 2009). The prevalence was reached to $15.7 \%$ in Turkey in Chronic Renal Disease in Turkey (CREDIT) data (Süleymanlar, 2011, p. 1862).

Eating disorders and loss of appetite are frequent complications of uremic syndrome which contribute to malnutrition in dialysis patients (Bossola et al., 2005). Nutritional requirement of hemodialysis (HD) patients are high, and intake of some nutrients frequently inadequate (Şanlier \& Demircioğlu, 2007). Malnutrition characterized by inadequate proteincalorie intake and cachexia, which begin in early stages of CRF, are highly prevalent in dialysis patients (Locatelli et al., 2002). Malnutrition prevalence in chronic dialysis patients is between 10 and $60 \%$ (Mutsert et al., 2009) and this situation is strongly related with increased in length of hospital stay, morbidity and mortality (Segall et al., 2014; NKF. K/DOQI, 2000; Locatelli et al., 2002; Şanlier \& Demircioğlu, 2007). In addition to dialysis adequacy, nutritional status is related with improved the quality of life in HD patients. Anthropometric measurements, biochemical markers (albumin, prealbumin, transferrin, leptin etc.) and dietary intake records have great importance in determining the nutritional status of HD patients (Şanlier \& Demircioğlu, 2007; Akbulut et al., 2013).

Inadequate intake of energy and protein accelerates catabolic process and it's negatively affects the prognosis of the disease (Shinaberger et al., 2006; Dong, et al., 2011). Protein requirements are a key area of importance for the dietary management of patients on dialysis. (Ash, et al., 2006) According to National Kidney Foundation Kidney Disease Outcome Quality Initiative (NKF K/DOQI) the recommended daily energy intake for HD patients is $35 \mathrm{kcal} / \mathrm{kg}$ body weight/day for those who are less than 60 years of age and $30-35 \mathrm{kcal} / \mathrm{kg}$ body weight/day for individuals 60 years or older and the recommended dietary protein intake for clinically stable HD patients is $1.2 \mathrm{~g} / \mathrm{kg}$ body weight/day (NKF K/DOQI, 2000). This study planned and conducted for determining the nutritional status and biochemical markers of HD patients who were applied dietary therapy.

\section{Method and Materials}

\subsection{Participants}

This study was carried out on a hundred and thirty six (73 male, 63 female) patients undergoing hemodialysis three times/week at the dialysis unit at Ankara SSK Hospital and Ministry of Health, Ankara Hospital. Patients maintained HD treatment for $4.8 \pm 3.82$ years and they informed about purpose of the study, signed voluntary participation form and filled the questionnaires adhered to of the declaration of Helsinki (World Medical Association). The research project was approved by the Gazi University, Faculty of Health Science.

\subsection{Dietary assessment}

The detailed 24-hour dietary records were taken from each individual. We estimated the volume and portion size from a photographs catalogue which included 120 pictures of food, each with 3-5 different portion size (Rakicioglu et al., 2009). Dietary recall was enrollment by three 
experienced dietitians and reviewed all questionnaires with the subject, probing for inaccurate and omitted responses. The average energy and nutrient intake for each patient's diet were analyzed using food composition tables for preparing Turkish foods (Bebis, 2004).

\subsection{Anthropometric measurements}

All measurements were taken by experienced dieticians. The weights of the subjects were measured with a portable scale to the nearest $0.1 \mathrm{~kg}$ with light clothes. Heights were measured with the subjects standing with no shoes and heels together, arms at the side, legs straight, shoulders relaxed, and head in the frankfort horizontal plane (Şanlier \& Demircioğlu, 2007). BMI $\left(\mathrm{kg} / \mathrm{m}^{2}\right)$ was calculated as weight divided by height. Those with a BMI below $18.5 \mathrm{~kg} / \mathrm{m}^{2}$ was considered underweight, a BMI between 18.5 and $24.9 \mathrm{~kg} / \mathrm{m}^{2}$ was indicate normal weight, a number above $25.0 \mathrm{~kg} / \mathrm{m}^{2}$ was considered overweight and a number above was $30.0 \mathrm{~kg} / \mathrm{m}^{2}$ were considered as obese (WHO, 2013).

\subsection{Biochemical markers}

Fasting blood glucose (FBG), urea, uric acid, creatinine, sodium $(\mathrm{Na})$, potassium $(\mathrm{K})$, chlorine $(\mathrm{Cl})$, calcium (Ca), phosphorus (P), alkaline phosphatase (ALP), serum glutamic oxaloacetic transaminase (SGOT), serum glutamic pyruvic transaminase (SGPT), cholesterol, total protein, albumin, parathormone (PTH), hemoglobin $(\mathrm{Hg})$, and hematocrit (Hct) were determined by the usual laboratory tests at the Hospital. Serum leptin was analyzed by a DIAsource Leptin EASIA-Kit (DIAsource ImmunoAssays S.A. - Rue du Bosquet, 2 - B-1348 Louvain-la-Neuve - Belgium Catologue no: KAP2281) at Gazi University Hospital.

\subsection{Statistical analysis}

The data analysis was carried out using SPSS version 15.0 software (SPSS Inc., Chicago, IL, USA). Results were expressed as mean $(\overline{\boldsymbol{x}})$ and standard deviation (SD) for the data. The differences between age, time on dialysis, height, body weight, BMI, biochemical determinations and daily energy-nutrient intakes by gender were evaluated by independent samples t-test. The interrelationship between daily energy and protein intake, BMI and biochemical finding (urea, total protein, albumin, leptin) were studied by Pearson's correlation. Significance defined as a $p$ value less than 0.05 .

\section{Results}

The study was conducted on 136 (73 male, 63 female) HD patients between the ages of 18-73 years. The mean age was found $45.5 \pm 13.51$ years and duration of HD was 4.8 \pm 3.62 years. Duration of HD was $3.5 \pm 2.86$ years in males, $6.4 \pm 3.80$ years in females and duration of HD in females was higher significantly than males $(p=0.000)$. Mean BMI was $23.1 \pm 2.98 \mathrm{~kg} / \mathrm{m}^{2}$ in male and $21.9 \pm 3.06 \mathrm{~kg} / \mathrm{m}^{2}$ in female. Mean BMI of females was significantly lower than male $(\mathrm{p}=0.023$ ) (Table 1). According to BMIs, $7.4 \%$ of the patients were underweight, $75.7 \%$ of the patients were in the healthy weight and the remains (16.9\%) were obese (data was not shown). 
Yassibas, E., Sahin, G., \& Sanlier, N. (2016). Dietary intakes and some biochemical markers in hemodialysis patients. International Journal of Human Sciences, 13(1), 1355-1366. doi:10.14687/ijhs.v13i1.3564

Table 1: Age, duration of HD and some anthropometric measurements of HD patients

\begin{tabular}{lccccc}
\hline & Male (n:73) & Female (n:63) & Total (n:136) & t & p \\
& $\overline{\boldsymbol{x}} \pm$ SD & $\overline{\boldsymbol{x}} \pm$ SD & $\overline{\boldsymbol{x}} \pm$ SD & & \\
\hline Age (years) & $47.1 \pm 14.30$ & $43.7 \pm 12.39$ & $45.5 \pm 13.51$ & 1.477 & 0.142 \\
Duration of HD (year) & $3.5 \pm 2.86$ & $6.4 \pm 3.80$ & $4.8 \pm 3.62$ & -5.079 & $0.000^{*}$ \\
Body weight $(\mathrm{kg}){ }^{*}$ & $64.6 \pm 9.56$ & $55.4 \pm 8.98$ & $60.3 \pm 10.34$ & 5.741 & $0.000^{*}$ \\
Height $(\mathrm{cm})$ & $167.1 \pm 7.39$ & $159.0 \pm 4.31$ & $163.4 \pm 7.36$ & - & - \\
BMI $\left(\mathrm{kg} / \mathrm{m}^{2}\right)$ & $23.1 \pm 2.98$ & $21.9 \pm 3.06$ & $22.5 \pm 3.07$ & 2.306 & $0.023^{*}$ \\
\hline
\end{tabular}

$* \mathrm{p}<0.05$

The serum levels of some biochemical markers of patients were shown in Table 2. Serum urea $(143.8 \pm 39.14 \mathrm{mg} / \mathrm{dL})$ and phosphorus $(7.1 \pm 6.07 \mathrm{mg} / \mathrm{dL})$ levels of HD patients were found above the references. The mean serum albumin $(3.9 \pm 0.43 \mathrm{~g} / \mathrm{dL})$ and total protein $(7.1 \pm 0.54$ $\mathrm{g} / \mathrm{dL})$ levels were normal but $\mathrm{Hb}(10.5 \pm 1.68 \mathrm{~g} / \mathrm{dL})$ and Hct $(31.8 \pm 4.85 \%)$ levels were below the acceptable levels. When the serum PTH levels evaluated, it was found that serum PTH levels of HD patients $(260.8 \pm 327.47 \mathrm{pg} / \mathrm{mL})$ considerably higher than reference $(12-65 \mathrm{pg} / \mathrm{mL})$. The mean serum leptin level was found $24.5 \pm 39.45 \mathrm{ng} / \mathrm{mL}$.

The mean daily energy intake was $1203.9 \pm 506.29 \mathrm{kcal}$ in male patients and $1107.6 \pm 434.90$ $\mathrm{kcal}$ in female patients and the difference was not significant $(\mathrm{p}=0.240)$. Also, daily protein intakes in two genders were similar $(\mathrm{p}=0.194)$. The average energy and protein intake of patients' were $20.0 \pm 9.70 \mathrm{kcal} / \mathrm{kg} / \mathrm{day}$ and $0.8 \pm 0.35 \mathrm{~g} / \mathrm{kg} /$ day respectively. Daily energy percentage taken from carbohydrate, protein and fat were $52.9 \pm 9.03 \%, 15.8 \pm 3.37 \%, 31.3 \pm 7.52 \%$ in male and $53.0 \pm 10.19 \%, 15.7 \pm 3.19 \%, 31.4 \pm 8.68 \%$ in female, respectively. The mean dietary fiber intake were found approximately $17.5 \mathrm{~g} /$ day in both genders. Differences between daily cholesterol $(\mathrm{p}=0.016)$, vitamin $\mathrm{D}(\mathrm{p}=0.003)$ and calcium $(\mathrm{p}=0.028)$ intake compared by gender was found statistically significant (Table 3).

Energy and protein intakes of patients per body weight was evaluated according to nutritional guideline of K/DOQI in Table 4. Almost all the female patients' (93.7\%) daily energy intake were less than $35 \mathrm{kcal} / \mathrm{kg} /$ day and this value were $94.5 \%$ for males. When protein intakes were assessed, $91.8 \%$ of male patients' daily protein intake was less than $1.2 \mathrm{~g} / \mathrm{kg} / \mathrm{day}$ and in female, this value were $84.1 \%$. 

International Journal of Human Sciences, 13(1), 1355-1366. doi:10.14687/ijhs.v13i1.3564

Table 2: Biochemical markers of HD patients

\begin{tabular}{lccc}
\hline Biochemical Markers & $\overline{\boldsymbol{x}} \pm$ SD & Minimum-Maximum & References \\
\hline FBG $(\mathrm{mg} / \mathrm{dL})$ & $90.7 \pm 21.92$ & $60.0-172.0$ & $70-100$ \\
Urea $(\mathrm{mg} / \mathrm{dL})$ & $143.8 \pm 39.14$ & $2.0-217.0$ & $5-25$ \\
Creatinine (mg/dL) & $8.4 \pm 1.66$ & $3.8-11.9$ & $0.6-1.1$ \\
Uric acid (mg/dL) & $5.5 \pm 1.32$ & $3.1-9.3$ & $2.6-7.2$ \\
Total protein (g/dL) & $7.1 \pm 0.54$ & $5.1-8.3$ & $6.4-8.5$ \\
Albumin (g/dL) & $3.9 \pm 0.43$ & $2.8-4.8$ & $3.5-5.0$ \\
Sodium (mmol/L) & $138.1 \pm 4.02$ & $126.0-150.0$ & $135-146$ \\
Potassium (mmol/L) & $4.9 \pm 0.70$ & $3.4-6.8$ & $3.5-5.3$ \\
Chlorine (mmol/L) & $102.7 \pm 8.13$ & $48.0-116.0$ & $96-108$ \\
Calcium (mg/dL) & $9.1 \pm 0.96$ & $7.2-11.4$ & $8.2-10.6$ \\
Phosphorus (mg/dL) & $7.1 \pm 6.07$ & $2.6-46.0$ & $2.5-4.5$ \\
ALP (U/L) & $246.6 \pm 169.06$ & $64.0-798.0$ & $30-120$ \\
PTH (pg/mL) & $260.8 \pm 327.47$ & $13.8-1732.0$ & $12-65$ \\
Cholesterol (mg/dL) & $158.9 \pm 31.84$ & $98.0-239.0$ & $110-200$ \\
SGOT (U/L) & $12.5 \pm 5.13$ & $5.0-32.0$ & $0-40$ \\
SGPT (U/L) & $15.9 \pm 8.68$ & $7.0-56.0$ & $0-40$ \\
Hemoglobin (g/dL) & $10.5 \pm 1.68$ & $6.2-14.6$ & $12-16$ \\
Hematocrit (\%) & $31.8 \pm 4.85$ & $19.4-43.5$ & $36-46$ \\
Leptin (ng/mL) & $24.5 \pm 39.45$ & $0.0-136.9$ & - \\
\hline
\end{tabular}

Table 3: Daily energy and nutrients intake of HD patients

\begin{tabular}{|c|c|c|c|c|c|}
\hline & $\begin{array}{c}\text { Male (n:73) } \\
\bar{x} \pm \text { SD }\end{array}$ & $\begin{array}{c}\text { Female (n:63) } \\
\bar{x} \pm \text { SD }\end{array}$ & $\begin{array}{c}\text { Total (n:136) } \\
\bar{x} \pm \text { SD }\end{array}$ & $\mathrm{t}$ & $\mathbf{P}$ \\
\hline Energy (kcal) & $1203.9 \pm 506.29$ & $1107.6 \pm 434.90$ & $1159.3 \pm 475.29$ & 1.179 & 0.240 \\
\hline Energy $(\mathrm{kcal} / \mathrm{kg})$ & $19.6 \pm 10.53$ & $20.5 \pm 8.69$ & $20.0 \pm 9.70$ & -0.574 & 0.567 \\
\hline Protein $(\mathrm{g})$ & $44.9 \pm 16.14$ & $41.4 \pm 14.90$ & $43.3 \pm 15.62$ & 1.305 & 0.194 \\
\hline Protein $(\mathrm{g} / \mathrm{kg})$ & $0.7 \pm 0.36$ & $0.8 \pm 0.33$ & $0.8 \pm 0.35$ & -0.690 & 0.492 \\
\hline Protein $(\%)$ & $15.8 \pm 3.37$ & $15.7 \pm 3.19$ & $15.7 \pm 3.28$ & 0.097 & 0.923 \\
\hline Carbohydrate $(\%)$ & $52.9 \pm 9.03$ & $53.0 \pm 10.19$ & $52.9 \pm 9.55$ & -0.076 & 0.939 \\
\hline Fat $(\%)$ & $31.3 \pm 7.52$ & $31.4 \pm 8.68$ & $31.3 \pm 8.05$ & -0.077 & 0.939 \\
\hline Cholesterol (mg) & $135.2 \pm 60.39$ & $107.9 \pm 70.32$ & $122.6 \pm 66.35$ & 2.434 & $0.016^{*}$ \\
\hline Fiber $(\mathrm{g})$ & $17.5 \pm 8.26$ & $17.5 \pm 8.20$ & $17.5 \pm 8.21$ & -0.013 & 0.990 \\
\hline Vitamin D $(\mu \mathrm{g})$ & $0.9 \pm 0.50$ & $0.6 \pm 0.50$ & $0.8 \pm 0.52$ & 3.062 & $0.003^{*}$ \\
\hline Folat $(\mu \mathrm{g})$ & $101.9 \pm 40.67$ & $94.9 \pm 40.61$ & $98.6 \pm 40.65$ & 1.005 & 0.317 \\
\hline Vitamin B12 ( $\mu \mathrm{g})$ & $2.5 \pm 2.65$ & $1.9 \pm 0.97$ & $2.2 \pm 2.06$ & 1.684 & 0.094 \\
\hline Calcium (mg) & $522.7 \pm 192.28$ & $448.1 \pm 198.11$ & $488.1 \pm 197.83$ & 2.222 & $0.028 *$ \\
\hline Phosphorus (mg) & $720.3 \pm 243.83$ & $656.9 \pm 240.20$ & $690.9 \pm 243.34$ & 1.522 & 0.130 \\
\hline $\operatorname{Iron}(\mathrm{mg})$ & $7.8 \pm 3.53$ & $7.9 \pm 3.35$ & $7.9 \pm 3.43$ & -0.081 & 0.936 \\
\hline Sodium (mg) & $1359.1 \pm 727.60$ & $1216.6 \pm 650.56$ & $1293.1 \pm 698.45$ & 1.189 & 0.237 \\
\hline Potassium (mg) & $1493.7 \pm 585.28$ & $1557.6 \pm 695.00$ & $1523.3 \pm 636.83$ & -0.583 & 0.561 \\
\hline
\end{tabular}

$* \mathrm{P}<0.05$ 
Yassibas, E., Sahin, G., \& Sanlier, N. (2016). Dietary intakes and some biochemical markers in hemodialysis patients. International Journal of Human Sciences, 13(1), 1355-1366. doi:10.14687/ijhs.v13i1.3564

Table 4: Energy and protein intakes of patients according to nutritional guideline of K/DOQI

\begin{tabular}{lccccccc}
\hline & & \multicolumn{2}{c}{ Male (n:73) } & \multicolumn{2}{c}{ Female (n:63) } & \multicolumn{2}{c}{ Total (n:136) } \\
Classification & & $\mathbf{n}$ & $\mathbf{0}$ & $\mathbf{n}$ & $\mathbf{\%}$ & $\mathbf{n}$ & $\mathbf{\%}$ \\
\hline Energy (kcal/kg/day) & & & & & & & \\
\hline & $<\mathbf{3 5}$ & 69 & 94.5 & 59 & 93.7 & 128 & 94.1 \\
& $\geq 35$ & 4 & 5.5 & 4 & 6.3 & 8 & 5.9 \\
\hline Protein (g/kg/day) & & & & & & & \\
\hline & $<1.2$ & 67 & 91.8 & 53 & 84.1 & 120 & 88.2 \\
& $\geq 1.2$ & 6 & 8.2 & 10 & 15.9 & 16 & 11.8 \\
\hline
\end{tabular}

There were positive correlation between serum total protein levels and daily energy $(\mathrm{r}=0.178, \mathrm{p}=0.039)$, and protein $(\mathrm{r}=0.201, \mathrm{p}=0.019)$ intake and also between serum albumin levels and daily protein $(\mathrm{g} / \mathrm{kg} /$ day $)(\mathrm{r}=0.210, \mathrm{p}=0.014)$ intake. Also, it was not found significant correlation between BMI and serum leptin levels $(\mathrm{p}=0.253)$ (Table 5).

Table 5: Correlations between BMI, energy and protein intake and biochemical markers

\begin{tabular}{lcccccc}
\hline Biochemical Determinations & \multicolumn{2}{c}{$\begin{array}{c}\text { Energy } \\
\text { (kcal/kg/day) }\end{array}$} & \multicolumn{2}{c}{$\begin{array}{c}\text { Protein } \\
(\mathbf{g} / \mathbf{k g} / \mathbf{d a y})\end{array}$} & \multicolumn{2}{c}{$\begin{array}{c}\text { BMI } \\
\left(\mathbf{k g} / \mathbf{m}^{2}\right)\end{array}$} \\
\hline & $\mathbf{r}$ & $\mathbf{p}$ & $\mathbf{r}$ & $\mathbf{p}$ & $\mathbf{r}$ & $\mathbf{p}$ \\
\cline { 2 - 7 } & 0.127 & 0.142 & 0.068 & 0.430 & $0.170^{*}$ & 0.048 \\
Urea $(\mathrm{mg} / \mathrm{dL})$ & $0.178^{*}$ & 0.039 & $0.201^{*}$ & 0.019 & -0.067 & 0.441 \\
Total protein $(\mathrm{g} / \mathrm{dL})$ & 0.156 & 0.070 & 0.210 & $0.014^{*}$ & -0.101 & 0.242 \\
Albumin $(\mathrm{g} / \mathrm{dL})$ & 0.076 & 0.376 & 0.068 & 0.434 & 0.099 & 0.253 \\
\hline Leptin $(\mathrm{ng} / \mathrm{mL})$ & & & & & & \\
\hline
\end{tabular}

${ }^{*} \mathrm{P}<0.05$

\section{Discussion}

Assessment of nutritional status has a vital importance for HD patients especially for those at risk with malnutrition. Malnutrition is prevalent up to $89 \%$ (İkizler, 2013) and related with cardiovascular disease (CVD), inflammation, low quality of life and increased morbidity and mortality (Locatelli et al., 2002; Şanlier \& Demircioğlu, 2007; Mazairac et al., 2011) . Dialysis related factors such as dialysis inadequacy and nutrient losses, metabolic and hormonal disturbance and also inadequate food consumption have an important role in malnutrition development (İkizler, 2013). Accumulation of uremic toxins and presence of different comorbid situations (diabetes, infections etc.) are associated with anorexia and decreased energy and protein intake, dietary restrictions because of disease also deteriorate malnutrition (Locatelli et al., 2002). Energy intake was actually low in HD patients. It is emphasized that the mean energy intake is $23-28 \mathrm{kcal} / \mathrm{kg} /$ day and protein intake $0.95-1.0 \mathrm{~g} / \mathrm{kg} /$ day in HD patients (Kovesdy, Shinaberger \& Kalanter-Zadeh, 2010). In this present study, it was found that mean energy and protein intake of patients was $20.0 \pm 9.701 \mathrm{kcal} / \mathrm{kg} /$ day and $0.8 \pm 0.35 \mathrm{~g} / \mathrm{kg} /$ day, respectively. These findings are evidence for how far HD patients meet the recommendations. In NKF K/DOQI guideline, the recommended daily energy intake for $\mathrm{HD}$ patients is $35 \mathrm{kcal} / \mathrm{kg}$ body weight/day for those who are less than 60 years of age and $30-35 \mathrm{kcal} / \mathrm{kg}$ body weight/day for individuals 60 years or older and the recommended dietary protein intake for clinically stable HD patients is $1.2 \mathrm{~g} / \mathrm{kg}$ body weight/day for positive nitrogen balance and at least $50 \%$ of the dietary protein (from animal 
Yassibas, E., Sahin, G., \& Sanlier, N. (2016). Dietary intakes and some biochemical markers in hemodialysis patients. International Journal of Human Sciences, 13(1), 1355-1366. doi:10.14687/ijhs.v13i1.3564

protein) should be of high biological value (NKF. K/DOQI, 2000). Compared with these recommendations most of patients could not meet energy $(94.1 \%)$ and $(88.2 \%)$ protein requirements. In fact, because of preventing the use of protein as an energy source with gluconeogenesis pathway, it is important to provide adequate energy. Otherwise positive nitrogen balance cannot be achieved in spite of high protein intake (Na1r, 2005). Energy intake below the recommendations $(<35 \mathrm{kkal} / \mathrm{kg} / \mathrm{d})$ is related with 1.22 times higher malnutrition risk in hemodialysis patients (Freitas et al., 2014). Hemodialysis has net effect with nitrogen losses from skeletal muscle. Important decline in mortality with increased protein intake has been reported (Chen et al., 2016). In the case of prolonged inadequate dietary intake, it will trigger malnutrition development. Protein intakes below $1.2 \mathrm{~g} / \mathrm{kg} /$ day in these patients have been stated to increase the rate of morbidity and mortality (Segall et al., 2009). In addition, carbohydrates should be $55 \%$ to $60 \%$ and fat should be $30 \%$ to $35 \%$ of total energy input and fiber intake should be $20-25$ $\mathrm{g} /$ day and carbohydrate and fiber intakes were below in this study.

PEM is an important cause of decreased albumin synthesis. Serum albumin reflects adequacy of visceral protein storage. Therefore, serum albumin is the most commonly used nutritional marker in HD patients. Decrease in albumin synthesis, increase in albumin catabolism and external albumin synthesis and changes in albumin distribution volume can be respected as causes of hypoalbuminemia in HD patients (Chazot et al., 2001). In our study, the mean level of serum albumin was normal (Table 2) and correlated with dietary protein intake (Table 5). It is thought that the mean serum albumin levels were within normal levels due to normal body weight of most individuals $(75.7 \%)$.

The creatinine level before dialysis is a strong predictor of low muscle mass and poor outcome (Patel et al., 2013; Yildiz \& Tufan, 2015). Although inadequate protein intake, high serum urea, uric acid and creatinine levels were observed in present study. Inadequate energy intake and hemodialysis therapy itself can increase protein catabolism and it will result in increase serum levels of protein catabolism products such as urea, uric acid and creatinine (Ikizler et al., 2002; Raj et al., 2004; Şanlıer \& Demircioglu, 2007). These parameters are also indicators of dialysis adequacy.

Poor energy and protein intake can cause nutrient deficiency. Especially iron and calcium inadequacy is inevitable in case of low consumption of protein rich foods and our data support this condition. Low dietary iron intake can trigger anemia, a prevalent complication of dialysis because of blood losses and impaired erythropoietin production (Kalantar-Zadeh \& Aronoff, 2009) and similarly hemoglobin and hematocrit levels were low in this study. Renal osteodystrophy and vascular calcification are complications frequently observed in ESRD patients which can be attributed to inadequate dietary calcium intake (Moe et al., 2006). CVD is a major cause of death in HD patients and vascular calcification is one of the main mechanisms of CVD. So, prolonged low calcium intake can be a risk factor for these complications.

While low serum albumin with low serum phosphorous levels is a predictor of poor nutrition, it will reflect worse prognosis co-existence with high phosphorus levels. In ESRD patients due to reduction of GFR, abnormal phosphorus homeostasis and positive phosphorus balance is common because of insufficient urinary phosphorus excretion (Ramirez et al.,1986). Inability to control of serum phosphorus levels causes an increase in calcium phosphorus products play a critical role in vascular calcification, CVD, calciphylaxis and death (Levin \& Hoenich, 2001). Epidemiological studies have shown that high phosphorus level associate with increased death risk (Tentori et al., 2008; Noori et al., 2010). According to KDOQI nutritional guideline, recommendation amount of daily phosphorus intake is $800-1000 \mathrm{mg}$ and in present study the mean phosphorus intake was below the recommendations $(690.96 \pm 243.34 \mathrm{mg} /$ day), 
(Table 3). Low dietary phosphorus intake is associated with lack of adequate protein intake. But we also found that phosphorus levels of HD patients in high and it may caused inadequacy of dialysis or phosphate binders (Stark et al., 2011; Mafra et al., 2012).

It is reported that vitamin-mineral supplementation in longtime dialysis patients is necessary. But these supplementations will be used cautiously according to biochemical findings. While in these patients supplementation of water soluble vitamins is recommended because of poor intake, metabolic disturbances, drug therapy and losses with dialysis, supplementation of fat soluble vitamins is controversial (NKF. K/DOQI, 2000). This study showed that folate, vitamin $\mathrm{B} 12$ and vitamin $\mathrm{D}$ intakes were below the recommendations (Table 3 ).

Leptin is a plasma protein synthesized in adipocytes and plays an important role in the regulation of food intake and energy expenditure (Stenvinkel, Lonnqvist \& Schalling, 1999). Studies about leptin levels in ESRD patients stated that all patients whether they received dialysis treatment or not have higher serum leptin levels due to decreased renal clearance (Nordfors et al., 1998; Bossola et al., 2004). The increase in leptin levels can cause impairment regulation of food intake in ESRD patients, so emerged as the most important causes of anorexia (Odamaki et al., 1999). Young et al (Young et al., 1997) were shown that leptin may play a role in the development of malnutrition because of high leptin levels and low protein intakes are related with low muscle mass. In present study, mean serum leptin level of patients was above the reference (Table 2). Leptin levels were not correlated with BMI and it can be thought that because of study group almost with healthy BMI and lack of body composition analysis. Likewise, energy and protein intake were not associated with leptin levels. There are some studies showed no relationship between dietary intake and serum leptin (Young et al., 1997; Wright et al., 2004; Bossola et al., 2005). These studies were supported in present study results.

\section{Conclusion}

Malnutrition, an important parameter for success of treatment, mainly is based on low energy and protein intake and can be reversible with ideal diet therapy. To provide proper nutritional treatment evaluation of nutritional status periodically with biochemical parameters, anthropometric measurements, and assessing energy and nutrient intakes with food diaries and 3 consecutive daily food records are recommended. These are also important for preventing unnecessary dietary limitations which can cause malnutrition.

\section{Acknowledgements}

We would like to thank all the participants who devoted their time to participate in this study. Their helpful and wholehearted cooperation is warmly acknowledged. Written informed consent was obtained from patients who participated in this study.

\section{References}

Akbulut, G., Şanlıer, N., İnal, S., Acar Tek, N., Öneç, K., \& Erten, Y. (2013). Daily dietary energy and macronutrient intake and anthropometric measurements of the peritoneal dialysis patients. Renal Failure, 35, 56-61. doi: 10.3109/0886022X.2012.734768.

View Article: DOI: http://dx.doi.org/10.3109/0886022X.2012.734768 
Yassibas, E., Sahin, G., \& Sanlier, N. (2016). Dietary intakes and some biochemical markers in hemodialysis patients. International Journal of Human Sciences, 13(1), 1355-1366. doi:10.14687/ijhs.v13i1.3564

Ash, S., Campbell, K.L., MacLaughlin, H., \& McCoy, E. (2006). Evidence based practice guidelines for the nutritional management of chronic kidney disease. Nutrition and Dietetics, 63 (suppl 2), 33-45. DOI: 10.1111/j.1747-0080.2006.00100.x

View Article: DOI: http://dx.doi.org/10.1111/j.1747-0080.2006.00100.x

Bebis Nutrition Data Base Software Data Base. (2004). The German Food Code and Nutrient Data Base (BLS II.3, 1999) with additions from USDA-sr and other sources, İstanbul, Turkey.

Bossola, M., Muscaritoli, M., Tazza, L., Panocchia, N., Liberatori, M., Giungi, S., et al. (2005). Variables associated with reduced dietary intake in hemodialysis patients. Journal of Renal Nutrition, 15, 244-252. doi: 10.1053/j.jrn.2005.01.004

View Article: DOI: http://dx.doi.org/10.1053/j.jrn.2005.01.004

Bossola, M., Muscaritoli, M., Valenza, V., Panocchia, N., Tazza, L., Cascino, A., et al. (2004). Anorexia and serum leptin levels in hemodialysis patients. Nephron Clinical Practice, 97, c76c82. doi:10.1159/000078634.

View Article: DOI: http://dx.doi.org/10.1159/000078634.

Chazot, C., Laurent, G., Charra, B., Blanc, C., VoVan, C., Jean, G., et al. (2001). Malnutrition in long term hemodialysis survivors. Nephrology Dialysis Transplantation, 16(1), 61-69. doi: $10.1093 / \mathrm{ndt} / 16.1 .61$

View Article: DOI: $\underline{\text { http://dx.doi.org/10.1093/ndt/16.1.61 }}$

Coresh, J., Selvin, E., Stevens, L.A., Manzi, J., Kusek, J.W., Eggers, P., et al. (2007). Prevalence of chronic kidney disease in the United States. The Journal of the American Medical Association, 298(17), 2038-2047. doi:10.1001/jama.298.17.2038

View Article: DOI: http://dx.doi.org/10.1001/jama.298.17.2038

Dong, J., Li, Y., Xu, Y., \& Xu, R. (2011). Daily protein intake and survival in patients on peritoneal dialysis. Nephrology Dialysis Transplantation, 26, 3715-3721. doi: $10.1093 / \mathrm{ndt} / \mathrm{gfr} 142$.

View Article: DOI: http://dx.doi.org/10.1093/ndt/gfr142

Freitas, A.T.V.S., Vaz, I.M.F., Ferraz, S.F., Peixoto, M.R.G., \& Campos, M.I.V.M. (2014). Prevalence of malnutrition and associated factors in hemodialysis patients. Revista de Nutrição, Campinas, 27(3), 357-366.

View Article: DOI: http://dx.doi.org/10.1590/1415-52732014000300009

Global Database on BMI, WHO. [cited 2013 10.07.2013]; Available from: http://apps.who.int/bmi/index.jsp?introPage $=$ intro 3. html

Ikizler, T., Pupim, L.B., Brouillette, J.R., Levenhagen, D.K., Farmer, K., Hakim, R.M., \& Flakoll, P.J. (2002). Hemodialysis stimulates muscle and whole body protein loss and alters substrate oxidation. American Journal of Physiology - Endocrinology and Metabolism, 282, 107116.

İkizler, T.A. (2013). Optimal nutrition in hemodialysis patients. Advances in Chronic Kidney Disease, 20, 181-189. 
Yassibas, E., Sahin, G., \& Sanlier, N. (2016). Dietary intakes and some biochemical markers in hemodialysis patients. International Journal of Human Sciences, 13(1), 1355-1366. doi:10.14687/ijhs.v13i1.3564

Kalantar-Zadeh, K., \& Aronoff, G.R. (2009). Hemoglobin variability in anemia of chronic kidney disease. Journal of the American Society of Nephrology, 20, 479-87. doi:10.1681/ASN.2007070728.

View Article: DOI: http://dx.doi.org/10.1681/ASN.2007070728

Kalantar-Zadeh, K., Block, G., McAllister, C.H., Humphreys, M.H., \& Kopple, J.D. (2004). Appetite and inflammation, nutrition, anemia, and clinical outcome in hemodialysis patient. American Journal of Clinical Nutrition, 80, 299 -307.

Kovesdy, C.P., Shinaberger, C.S., \& Kalanter-Zadeh, K. (2010). Epidemiology of dietary nutrient intake in ESRD. Seminars in Dialysis, 23, 353-358. doi: 10.1111/j.1525-139X.2010.00745.x.

View article: DOI: http://dx.doi.org/10.1111/j.1525-139X.2010.00745.x.

Levin, N.W. \& Hoenich, N.A. (2001). Consequences of hyperphosphatemia and elevated levels of the calcium-phosphorus product in dialysis patients. Current Opinion Nephrology and Hypertension, 10, 563-568.

Locatelli, F., Fouque, D., Heimburger, O., Drüeke, T.B., Cannata-Andia, J.B., Hörl, W.H., \& Ritz, E. (2002). Nutritional status in dialysis patients: a European consensus. Nephrology Dialysis Transplantation, 17, 563-572. doi: 10.1093/ndt/17.4.563.

View Article: DOI: http://dx.doi.org/10.1093/ndt/17.4.563

Mafra, D., Moraes, C., Leal, V.O., Farage, N.E., Stockler-Pinto, M.B., \& Fouque, D. (2012). Underreporting of energy intake in maintenance hemodialysis patients: a cross-sectional study. Journal of Renal Nutrition, 22, 578-583. doi: 10.1053/j.jrn.2011.10.037.

View Article: DOI: $\underline{\text { http://dx.doi.org/10.1053/j.jrn.2011.10.037 }}$

Mazairac, A.H.A., de Wit, G.A., Penne, E.L., van der Weerd, N.C., Grooteman, M.P.C., van den Dorpel, M.A., et al. (behalf of the CONTRAST investigators). (2011). Protein-energy nutritional status and kidney disease-specific quality of life in hemodialysis patients. Journal of Renal Nutrition, 21, 376-386. doi: 10.1053/j.jrn.2010.08.004.

View Article: DOI: http://dx.doi.org/10.1053/j.jm.2010.08.004

Moe, S., Drüeke, T., Cunningham, J., Goodman, W., Martin, K., Olgaard, K., et al. (2006). Definition, evaluation, and classification of renal osteodystrophy: A position statement from kidney disease: Improving Global Outcomes (KDIGO). Kidney International, 69, 1945-1953.

Mutsert, R., Grootendorst, D.C., Boeschoten, E.W., Brandts, H., Manen, J.G.V., Krediet, RT, et al. (2009). Subjective global assessment of nutritional status is strongly associated with mortality in chronic dialysis patients. American Journal of Clinical Nutrition. 89(3), 787-93. doi: 10.3945/ajcn.2008.26970

View Article: DOI: http://dx.doi.org/10.3945/ajcn.2008.26970

Narr, K.S. (2005). Amino acid and protein metabolism in chronic renal failure. Journal of Renal Nutrition, 15, 34-38. doi: 10.1016/j.clnu.2010.02.005.

View Article: DOI: http://dx.doi.org/10.1016/i.clnu.2010.02.005

NKF. K/DOQI. (2000). Nutrition in chronic renal failure. American Journal of Kidney Diseases, 35, 6(Suppl2), S1-S140. 
Yassibas, E., Sahin, G., \& Sanlier, N. (2016). Dietary intakes and some biochemical markers in hemodialysis patients. International Journal of Human Sciences, 13(1), 1355-1366. doi:10.14687/ijhs.v13i1.3564

Noori, N., Kalantar-Zadeh, K., Kovesdy, C.P., Bross, R., Benner, D., \& Kopple, J.D. (2010). Association of dietary phosphorus intake and phosphorus to protein ratio with mortality in hemodialysis patients. Clinical Journal of the American Society Nephrology, 5, 683-692. doi: 10.2215/CJN.08601209.

View Article: DOI: http://dx.doi.org/10.2215/CJN.08601209

Nordfors, L., Lönnqvist, F., Heimbürger, O., Danielsson, A., Schalling, M., \& Stenvinkel, P. (1998). Low leptin gene expression and hyperleptinemia in chronic renal failure. Kidney International, 54, 1267-1275. doi:10.1046/j.1523-1755.1998.00088.x.

View Article: DOI: $\underline{\text { http://dx.doi.org/10.1046/j.1523-1755.1998.00088.x }}$

Odamaki, M., Furuya, R., Yoneyama, T., Nishikino, M., Hibi, I., Miyaji, K., \& Kumagai, H. (1999). Association of the serum leptin concentration with weight loss in chronic hemodialysis patients. American Journal of Kidney Diseases, 33, 361-368. doi: 10.1016/S02726386(99)70313-6.

View Article DOI: http://dx.doi.org/10.1016/S0272-6386(99)70313-6

Raj, D.S.C., Zager, P., Shah, V.O., Dominic, E.A., Adeniyi, O., Blandon, P., et al. (2004). Protein turnover and amino acid transport kinetics in end-stage renal disease. American Journal of Physiology Endocrinology and Metabolism, 286, 136-143.

View Article: DOI: http://dx.doi.org/10.1152/ajpendo.00352.2003

Rakicioglu, N., Tek-Acar, N., Ayaz, A., \& Pekcan, G. (2009). Meal and Food Catalog: Measurements and Quantities, 2nd ed. Ata Ofset Publications, Ankara, pp. 1-100.

Ramirez, J.A., Emmett, M., White, M.G., Fathi, N., Santa Ana, C.A., Morawski, S.G., \& Fordtran, J.S. (1986). The absorption of dietary phosphorus and calcium in hemodialysis patients. Kidney International, 30, 753-759. doi: 10.1038/ki.1986.252.

View Article: DOI: http://dx.doi.org/ 10.1038/ki.1986.252

Segall, L., Mardare, N.G., Ungureanu, S., Busuioc, M., Nistor, I., Enache, R., Marian, S., \& Covic, A. (2009). Nutritional status evaluation and survival in haemodialysis patients in one centre from Romania. Nephrology Dialysis Transplantation, 24, 2536-2540. doi: 10.1093/ndt/gfp110

View Article: DOI: http://dx.doi.org/10.1093/ndt/gfp110

Segall, L., Moscalu, M., Hogass S., Mititiuc, I., Nistor, I., Veisa, G., \& Covic, A. (2014). Proteinenergy wasting, as well as overweight and obesity, is a long-term risk factor for mortality in chronic hemodialysis patients. International Urology and Nephrology, 46, 615-621. doi: 10.1007/s11255-014-0650-0

View Article: DOI: http://dx.doi.org/10.1007/s11255-014-0650-0

Serdengeçti, K., Süleymanlar, G., Altiparmak, M., \& Seyahi, N. (2009). Registry of the nephrology dialysis and transplantation in Turkey (Registry-2008) Istanbul: Published by the Turkish Society of Nephrology.

Shinaberger, C.S., Kilpatrick, R.D., Regidor, D.L., McAllister, C.J. Greenland, S., Kopple, J.D., \& Kalantar-Zadeh, K. (2006). Longitudinal associations between dietary protein intake and survival in hemodialysis patients. American Journal of Kidney Diseases, 48, 37-49. doi: 10.1053/j.ajkd.2006.03.049.

View Article: DOI: http://dx.doi.org/10.1053/j.ajkd.2006.03.049 

International Journal of Human Sciences, 13(1), 1355-1366. doi:10.14687/ijhs.v13i1.3564

Stark, S., Snetselaar, L., Hall, B., Stone, R.A., Kim, S., Piraino, B., \& Sevick, M.A. (2011). Nutritional intake in adult hemodialysis patients. Topics in Clinical Nutrition, 26, 45-56. doi:10.1097/TIN.0b013e3181faba4c.

View Article: DOI: http://dx.doi.org/10.1097/TIN.0b013e3181faba4c

Stenvinkel, P., Lonnqvist, F., \& Schalling, M. (1999). Molecular studies of leptin: Implications for renal disease. Nephrology Dialysis Transplantation, 14, 1103-1112. doi: $10.1093 / \mathrm{ndt} / 14.5 .1103$.

View Article: DOI: http://dx.doi.org/10.1093/ndt/14.5.1103

Süleymanlar, G., Utas, C., Arinsoy, T., Ateş, K., Altun, B., \& Altınparmak, M.R. (2011). A population based survey of chronic renal disease in Turkey-the CREDIT study. Nephrology Dialysis Transplantation, 26, 1862-1871. doi: 10.1093/ndt/gfq656.

View Article: DOI: http://dx.doi.org/10.1093/ndt/gfq656

Şanlier, N., \& Demircioğlu, Y. (2007). Correlation of dietary intakes and biochemical determinates of nutrition in hemodialysis patients. Renal Failure, 29, 213-218. doi:10.1080/08860220601098904

View Article: DOI: http://dx.doi.org/10.1080/08860220601098904

Tentori, F., Blayney, M.J., Albert, J.M., Gillespie, B.W., Kerr, P.G., Bommer, J., et al. (2008). Mortality risk for dialysis patients with different levels of serum calcium, phosphorus, and PTH: The Dialysis Outcomes and Practice Patterns Study (DOPPS). American Journal of Kidney Diseases, 52, 519-530. doi: 10.1053/j.ajkd.2008.03.020.

View Article: DOI: http://dx.doi.org/10.1053/j.ajkd.2008.03.020

Wright, M., Woodrow, G., O’Brien, S., Armstrong, E., King, N., Dye, L., et al. (2004). Cholecystokinin and leptin: their influence upon the eating behavior and nutrient intake of dialysis patients. Nephrology Dialysis Transplantation, 19, 133-140. doi: $10.1093 / \mathrm{ndt} / \mathrm{gfg} 471$.

View Article DOI: http://dx.doi.org/10.1093/ndt/gfg471

Young, G., Woodrow, G., Kendall, S., Oldroyd, B., Turney, J.H., Brownjohn, A.M., \&Smith, M.A. (1997). Increased plasma leptin/fat ratio in patients with chronic renal failure: a cause of malnutrition? Nephrology Dialysis Transplantation, 12, 2318-2323. doi: $10.1093 / \mathrm{ndt} / 12.11 .2318$.

View Article: DOI: http://dx.doi.org/10.1093/ndt/12.11.2318 